\title{
Causes and Minimization of Material Waste in Construction of Residential Buildings in Northern Nairobi
}

\author{
R. P. Mbote \\ ${ }^{1}$ Department of Building Science and Technology, \\ Technical University of Kenya, \\ Kenya
}

\author{
M. Makworo ${ }^{2}$ \\ ${ }^{2}$ Department of Landscape Architecture, \\ Jomo Kenyatta University of Agriculture and Technology, \\ Kenya
}

Masudi et al, 2012). Nugroho et al (2013) opine that if construction waste is managed properly, a saving of $6 \%$ of the project cost can be realized.

\begin{abstract}
Large amounts of material waste are generated in residential building construction in Northern Nairobi where conventional construction methods are predominant. This could be attributed to lack of cost effective building materials, technologies and material waste management systems in the region. Materials in a residential building project account for about 70 percent of the overall cost, thus making waste minimization in building project implementation a major area of concern. This study set out to establish factors causing material waste and measures for minimizing them in construction of residential building frames in Northern Nairobi. The research was designed as a case study and survey. Northern Nairobi was purposively sampled, due to high concentration of residential building projects. Convenience sampling was used to select project consultants who were handling projects within the research area. Primary data was gathered through interviews and structured observations. Quantitative and qualitative data were analyzed using descriptive statistics and thematic analysis respectively. The study identified diverse causes of material waste which were categorized into the following themes: resource material factors, design and site instruction factors, product manufacturing and delivery factors, environmental factors and site production and management factors. The study noted that, $69 \%$ of building developers prefer labour contracting in this region, despite its high contribution to material waste. Significant factors to be addressed in minimization of materials waste during construction include: quality purchases, experienced artisans/materials handlers, adequate supervision on material handling, scheduled material delivery and good material storage practices. It concludes that a transformation in the approach to construction of residential buildings in the region is necessary in order to significantly reduce material waste and save on the cost of construction.
\end{abstract}

Keywords: Building frame, causes, construction, Material waste, Nairobi.

\subsection{INTRODUCTION}

Construction of residential buildings, using the conventional methods generates unacceptable levels of material waste, leading to manpower waste, financial setbacks to contractors, significant impacts on health, aesthetics and the general environment. The amount and type of material waste depends on the stage of construction, type of construction work and practices on site. Waste minimization in implementation of a residential building project is a major area of concern, including waste management. Bosinnk and Brouwers (1996), aver that materials in a residential building project amounts to about $60 \%$ to $70 \%$ in the overall cost of construction. Various studies have confirmed that waste represents a large percentage of production costs in a residential building project, between $1-10 \%$ by weight of purchased materials. The amount of construction waste generated in any region depends on the general economic conditions of the vicinity (Bosinnk and Brouwers, 1996;
Generally, residential building construction activities which produce material waste can be grouped into off-site and onsite operational activities. Off-site activities include prefabrication, project design (architectural, structural, mechanical and electrical design), manufacturing, transporting of materials and components. On-site construction activities relate to construction of a physical facility which consists of the substructure and superstructure of the building (Muhwezi, et al, 2012).

In Kenya, material waste in construction is not only focused on the quantity of waste of materials on site but also on several activities in design and construction phase (Kioko, 2007). The construction industry in Kenya predominantly employs the conventional method of construction. This method of construction generates considerable volumes of material waste such as concrete rubble, natural stone rubble, block rubble and timber off-cuts.

The Government of the Republic of Kenya (2007) in Kenya vision 2030, envisaged production of 200,000 housing units annually by 2012 through different initiatives. The Ministry of Land, Housing and Urban Development was charged with the responsibility of promoting, among others, improving living environment for the citizens and promotion of low cost housing development through research on cost-effective building materials and technologies. The main objective was to facilitate Kenyans to access quality, affordable and sustainable housing. This however, has been hampered by a number of challenges, the main one being the high cost of building materials. The Government of Kenya is committed to delivery of affordable housing in her development agenda for the period $2018-2022$.

\subsection{Objectives of the Study}

Objectives of this study are:

1. To establish factors causing material waste in construction of residential building frames in Northern Nairobi

2. To establish measures for minimizing material waste in construction of residential building frames in Northern Nairobi. 


\subsection{LITERATURE REVIEW}

\subsection{The Concept of Construction Waste}

Construction waste in building projects is attributed to a number of factors. According to Pongracz et al (2004), waste management theory envisages four classifications of waste:

Class 1: Non-wanted things, created not intended, or not avoided, with no purpose.

Class 2: Things with a finite purpose thus destined to become useless after fulfilling the purpose.

Class 3: Things with well-defined purpose, but their performance ceased being acceptable due to a flaw in structure or state.

Class 4: Things with well-defined purpose, and acceptable performance, but their users failed to use them for their intended purpose.

There is an acceptable level of waste, which can only be reduced through a significant change in the level of technological development. The production process of residential building construction requires an integrated and rationalized approach so as to minimize material waste and realize an economical product. The technological techniques used in a particular site play a major role in minimization of construction waste.

\subsection{Categories of Material Waste in Building Sites}

There are different categories of material waste in the building construction process. According to Muhwezi, et al (2012), construction material waste can be classified into six broad categories: conversion waste, cutting waste, application waste, stockpile waste, residue waste and transit waste. In conventional residential building, the materials commonly used to erect the structural frame include concrete, wood, stones or blocks, steel, roof coverings (tile, metal sheets, asphalt, bitumen felts) and mortar.

According to Wang, et al (2008), the main causes of concrete waste generation include demolished concrete, over-ordering, variations between drawings and construction work, poor communication, on-site concreting activities, default from design drawings; design variations and default from delivering. The wastage is mainly from the mismatch between the quantity of concrete ordered and that required imperfect planning, project delays and unnecessary waste handling processes.

Wood waste refers to timber products, such as formwork, false work, plywood, framing, roof truss and others not properly utilized (Lau, et al2008). According to Wang et al (2008), major sources of timber wastes are wasted timber and cutovers. This may be attributed to periodic usage of formwork, storage, construction activities, unstandardized design operations, human behavior among other causes. Mortar is used to set stones, blocks and bricks as well as finishing work on walls and floors of buildings. The main cause of waste in mortar is scraping of mortar while pointing, mixing too much and spills around the site. Excess unused mortar at the end of day hardens ending up as waste.
Roof tile waste is mainly caused by sawing when insufficient attention is paid to available tile sizes and shapes during design phase. Collaboration between construction parties would improve on material waste minimization. Breakages during transportation can result to 15\% of amount purchased Bosinnk and Brouwers (1996).

\subsection{Material Waste Causes in Building Construction}

Different construction processes impact on material waste generation, including the quantity of waste produced. This may be attributed to a number of factors such as inaccurate or surplus ordering of materials, damage through handling errors, damage through inadequate storage, damage generated by poor co-ordination with other trades, rework due to low quality of work, inefficient use of materials and temporary works materials (WRAP, 2007). A study by Branco (2007) reveals that the most dominant types of waste occurring in construction projects are: waste of materials, over allocation of materials, rework, clarifications, unnecessary handling of materials, inefficient movement of workers, waste of space on site, and delays. The most common causes, for the occurrence of these types of waste include: poor design and specifications, not enough information, ambiguous information, poor jobsite layout, poor planning, lack of control, excessive quantity of materials, lack of work place available, weather conditions, poor qualification of production team and ineffective work methods.

In Kenya, a study by Kioko (2007) highlights thirteen factors which are significant variables that influence waste: productivity, contractors influence over design, method of communication between contractors and design consultants, incorporation of waste minimization in processes, lack of trade skills, slow and poor decision making, poor planning and scheduling, inappropriate construction methods, poor design, delay in equipment arrival, frequent equipment breakdown, materials not meeting specifications and lack of effective supervision. These factors are significant in cost, quality and time performance of a project.

\subsection{Measures for Reduction of Building Material Waste}

According to Josephson and Saukkoriipi (2007), reducing waste in building projects is one of the main challenges and should be among the priorities in the building sector as a whole. The emphasis should be: education to all workers and suppliers, focus on main process in the project, focus on manufacture and making inventories to gain knowledge of the size of different types of waste. Resource venture (2005) suggests three strategies to reduce a construction project's waste as including reduce, reuse and recycling.

Studies carried out by Josephson and Saukkoriipi (2007), Al-Hajj and Hamani (2011), emphasize, among others, on staff training as a way to curb excessive material waste in construction process. Dainty and Brooke (2004) suggests the following measures to curb building construction wastes: standardization of design, reduction of quantity of off-cuts; 
stock control; education of the workforce; provision of waste skips, just-in-time delivery strategy; contractual clauses to penalize poor waste performance; use of off-site prefabrication; on-site materials compaction. A study by Angaya (2012) sought to determine the extent of waste material management influence in the performance of housing building projects in Nairobi. The study noted that parameters describing the overall process of lean construction are considered important determinants of the performance of housing and building projects. The study also noted that there is a relationship between lean construction parameters and performance of housing scheme building projects in varying degrees.

\subsubsection{Construction waste management plan.}

Resource venture (2005) describes waste management plan as the mechanisms for interaction and oversight for controlling materials and waste. The management plan addresses methods of identification of the materials that need special handling and prescription of processes to minimize the risk of their unsafe use and improper disposal. Resource venture (2005) further points out that a construction waste management plan to reduce cost of wastes may include the following actions: restating the project's waste reduction goal, designating a recycling coordinator responsible for implementing the plan, identifying the waste materials expected, their disposal method and handling procedures and defining how the plan will be communicated to the working crew.

According to Wahab and Lawal (2011), waste index calculation on past projects could help in having prior understanding of the volume of waste to be generated, develop good planning of resources, and control the waste that may be generated by taking similar projects earlier handled as points of reference. The study recommends the following actions by contractors: ensure effective control of materials, evolve better means and facilities for storage, ensure sorting exercise is adequately carried out, encourage use of prefabricated elements, develop a waste management plan, ensure capacity building and manpower development.

\subsubsection{Integrated waste management plan (IWMP).}

United Nations Environment Program (n.d) opines that, the main goal of IWMP is to optimize waste management by maximizing efficiency, and minimizing associated environmental impacts and financial costs. The aim is to assist responsible parties to have plans, which comprise an optimum approach to IWM planning in terms of resource allocation, time scheduling and allocation of responsibilities.

According to the Department of environmental quality, Montana Government, USA (2013), the hierarchy of integrated waste management includes: source reduction which includes the design, manufacture, purchase, or use of materials or products, including packaging, reuse by using a product in its original form for a purpose that is similar to or different from the purpose that it was designed for, recycling by remanufacturing all or part of a product into a new product; composting, land filling and incineration.

\subsection{Construction Approaches \\ 2.5.1 Conventional Building}

According to Foster and Greeno (2006), conventional building is a mixture of traditional and new form of construction involving both old craft and use of expensive mechanized plants for most operations. Craftsmen carry out most of the work apart from specialized work in reinforced concrete and steelwork. With increasing size of buildings, there has been an increase in use of mechanical plants to increase the production. Badir et al (1998), cited in Kadir (2006), suggests four main categories of building system classification: conventional building system; cast in-situ formwork system (table or tunnel formwork); prefabricated system; and composite system. The last three building systems are mainly industrialized building systems where components of a building are conceived, planned, fabricated, transported and erected on site.

\subsubsection{Industrialized Building System}

Industrialized building systems (IBS) are methods to reduce the amount of site labor involved in building operations and to increase the productivity of the industry generally. Such methods should produce buildings at no greater cost than by conventional methods (Foster 1979). According to Kamar, et al (2011), IBS represents the prefabrication and construction industrialization concept and is an innovative process of building construction using concept of massproduction of industrialized systems. Foster and Greeno (2006) infer that IBS is continuity of production implying a steady flow of demand, standardization, and integration of different stages of the whole production process, a high degree of organization of work, mechanization, research and organized experimentation integrated with production.

\subsection{Systems Theory}

According to Capra ( 1997), cited in Mele et al (2009), systems theory is an interdisciplinary theory about every system in nature, in society and in many scientific domains as well as a framework in which a phenomenon can be investigated from a holistic approach. These concepts and principles of organization provide a basis for their unification (Heylighen and Josylyn, 1992). Systems theory focuses on the arrangement of and relationship between parts and how they would work together as a whole.

\subsubsection{Systems theory and Lean production.}

Lean production uses the just-in-time practices and aims at the rational use of resources, the strategies to improve the production process and the elimination of waste, and the use of managerial scientific techniques (Manea, 2013). Greg and Tariq (2012) avers that, lean construction is a production management-based approach to project delivery. It is a philosophy based on the concepts of lean manufacturing. Aziz and Hafez (2013) argues that one 
approach for improving the productivity of the construction industry is using lean construction which results from the application of a new form of production management to construction.

\subsection{Conceptual Framework}

By integrating systems thinking in residential building production process, an alternative approach to construction of residential building in Northern Nairobi is explored in this study. This approach is lean construction and its utilization minimizes material waste.
Lean construction is a systematic approach in construction process, where the owner, designer, contractors, suppliers/manufacturers work together to produce value adding, constructible, usable and maintainable facility. This maximizes on workflow, minimizes performance variations and eliminates systematic waste sources, the key cornerstone of lean construction. The primary objective of lean construction is to stimulate a system rethinking of the construction process both onsite and offsite and by providing a forum for disseminating knowledge and exchange of ideas between the industry and academia (Greg and Tariq, (2012). Figure 1 provides a summary of the conceptual framework guiding this study.

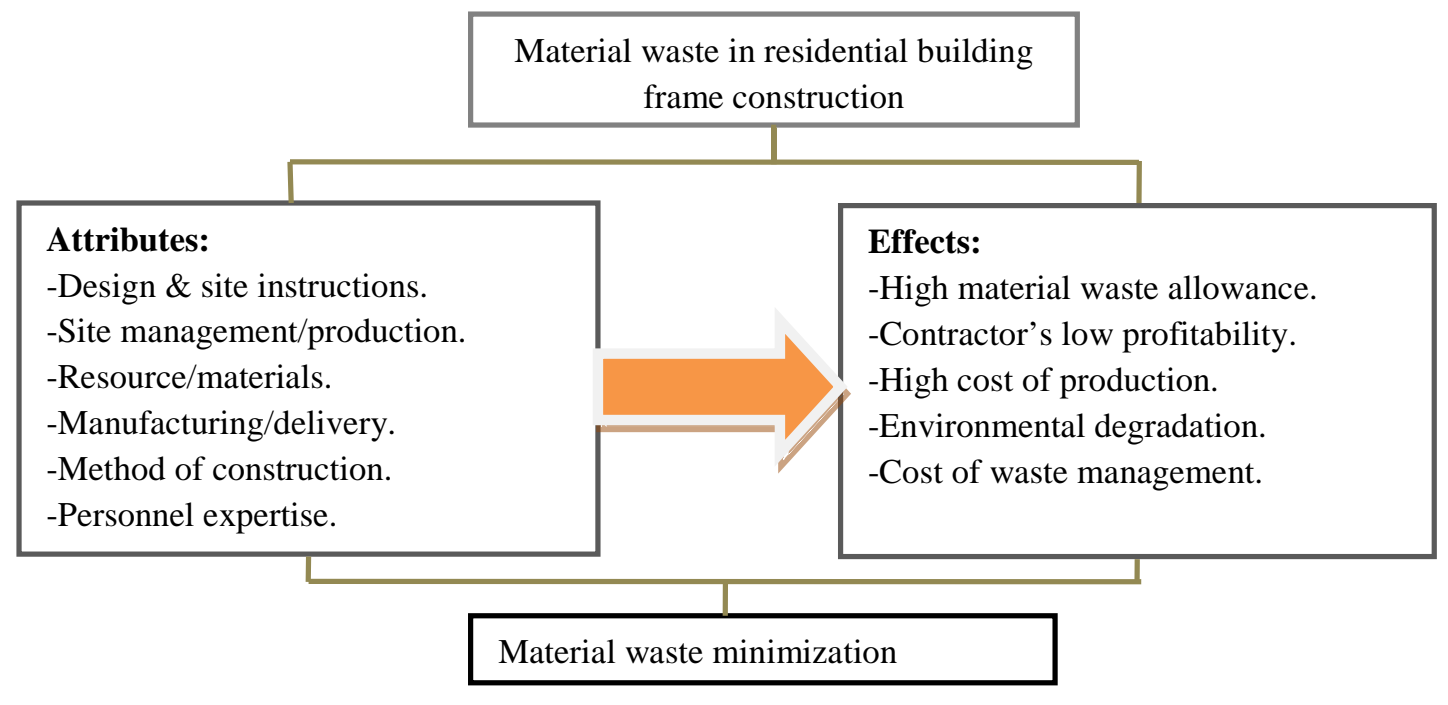

Figure 1: Summary of conceptual framework

\subsection{RESEARCH METHODOLOGY}

This research is designed as a survey and case study. Primary data is gathered from respondents through interviews, focus group discussions and observations. Purposive sampling technique was used to identify residential estates that are a focus of this study. As such, Clay City and Kasarani estates in Northern Nairobi are purposively sampled due to them having a high concentration of diverse and ongoing residential building projects whose construction had been advanced to roof level. Thirty three residential building projects were sampled of which 5 were maisonettes and 28 walk-up flats. Convenience sampling was used to select 32 project consultants who have handled projects within the research area. These included Project Managers, Architects, Engineers and Quantity surveyors.

\subsection{Data collection methods}

Primary data from project consultants was collected through structured interviews. Unstructured interviews were used to collect data from skilled site personnel in focus group discussions. Structured observation was conducted within the sampled projects to capture the type of contract, images of waste materials on site and methods of construction.

\subsection{Data analysis methods}

Data collected through focus group interviews, structured interviews and observations was analyzed by describing, structuring, categorizing, and scrutinizing the information into themes, to bring out factors attributed to materials waste in construction of a residential building frame in Northern Nairobi. Statistical Package for Social Science (SPSS), facilitated in organizing raw data into an array so that frequencies, percentages and other statistical functions were generated.

\subsection{RESEARCH RESULTS}

Responses from project consultants, focus group discussions and researcher observations on individual sites which had similar features were organized in five main thematic areas: Design and site instructions, site production and management, resource materials, manufacturing and delivery and environmental factors.

\subsection{Material waste causes}

To identify the general trend in residential project implementation in this region, project 
consultants were required to state the type of contract used on various projects. The results indicate a high percentage of $69 \%$ as labour only contracts. Full contracts (with bills of quantities) at $22 \%$ and direct labour contracts at $9 \%$ follow in that order. The results of perception for material waste causes, drawn from project consultants, which include the frequencies and percentages, are presented in table 1.

Table1: Project Consultants’ Perception of Material Waste Causes

\begin{tabular}{|c|c|c|}
\hline Attributes & Frequency & Percentage \\
\hline \multicolumn{3}{|l|}{ Design and site instruction factors } \\
\hline Site instructions/change of design midway & 15 & $24 \%$ \\
\hline Poor/complex design & 14 & $22 \%$ \\
\hline Unclear specifications & 6 & $10 \%$ \\
\hline Lack of proper documentation & 3 & $5 \%$ \\
\hline Inadequate co-ordination & 9 & $14 \%$ \\
\hline Non modular design & 9 & $14 \%$ \\
\hline Inadequate consultation & 7 & $11 \%$ \\
\hline \multicolumn{3}{|l|}{ Site production and management factors } \\
\hline Inadequate control/supervision & 12 & $20 \%$ \\
\hline Management work attitude & 2 & $3 \%$ \\
\hline Lack of security & 5 & $8 \%$ \\
\hline Inadequate/improper equipments & 1 & $2 \%$ \\
\hline Craftsmen inadequate training & 4 & $6 \%$ \\
\hline Demolition/rework & 3 & $5 \%$ \\
\hline Poor work conditions & 4 & $7 \%$ \\
\hline Inexperienced workers/contractor & 25 & $41 \%$ \\
\hline Poor site layout & 3 & $5 \%$ \\
\hline Change of contractors midway & 2 & $3 \%$ \\
\hline \multicolumn{3}{|l|}{ Material resource factors } \\
\hline Excessive/ Inadequate quantity & 23 & 22 \\
\hline Sub quality purchases & 13 & $13 \%$ \\
\hline Poor storage /poor storage facilities & 20 & $19 \%$ \\
\hline Misuse & 23 & $22 \%$ \\
\hline Theft /vandalism & 16 & $15 \%$ \\
\hline Improper handling & 9 & $9 \%$ \\
\hline \multicolumn{3}{|l|}{ Manufacturing/Delivery factors. } \\
\hline Low quality materials & 24 & $63 \%$ \\
\hline Poor handling/transportation & 8 & $21 \%$ \\
\hline Substandard sizes & 2 & $6 \%$ \\
\hline Improper specification for use & 2 & $5 \%$ \\
\hline Improper packaging & 2 & $5 \%$ \\
\hline \multicolumn{3}{|l|}{ Environmental factors } \\
\hline Material deterioration/contamination due to weather & 20 & $71 \%$ \\
\hline Damage by insects & 1 & $4 \%$ \\
\hline Natural calamities & 2 & $7 \%$ \\
\hline Topography & 5 & $18 \%$ \\
\hline
\end{tabular}

The focus group in every site included tradesmen, accountants, storekeepers and purchasing officers. During the discussions, the following factors were identified as the main causes of material waste in construction of a residential building frame in Northern Nairobi: client's change of design, unscheduled purchases, poor quality purchases and lack of proper documentation; Contractor/builder poor workmanship, attitude, improper 
supervision, insecurity, improper storage and de-motivated workers; change of design, poor/complex design, and unclear specifications by designers; inadequate training of craftsmen, inexperience, theft/pilferage, attitude/negligence, and lack of motivation; incremental weather, natural calamities, contamination, topography, insect attack; poor quality materials, transportation breakages or handling and dimensional deficiency. These factors were grouped in five thematic areas as for project consultants: Design and site instruction factors,site production and management factors, material resource factors, manufacturing/delivery factors and environmental factors. An observation schedule composed of site activities, type of development, images of material storage and images of material waste streams on each site guided the researcher on which items to be observed.

Factors attributed to material waste observed by the researcher include: substandard materials on site, poor storage practices, poor site layout, inadequate supervision, excessive materials on site, workers' attitude, weather effects, excessive off-cuts, demolition and rework, unskilled or untrained workers, unscheduled materials on site and methods of construction.

4.2 Measures for minimizing material waste in residential building frame construction in Northern Nairobi

Significant factors for minimizing material waste as suggested by both the project consultants and focus group discussions are highlighted in Table 2. Proper supervision of the project activities and materials incorporation rates highly at $24 \%$. Strict supervision ensures that materials are not wasted through breakages, poor workmanship leading to rework, unnecessary cuttings and strict adherence to the design to avoid repetitions. Sensitizing the working crew on the best practices on reduction of material wastage during construction is also rated highly at $23 \%$. This has the implication that the workers who handle and deal with the materials directly have a major role to play in ensuring material wastage is reduced to a minimum.

Table 2: Significant factors for minimizing material waste

$\begin{array}{lc}\text { Active factors } & \text { Frequency } \\ \text { Morning briefs } & 23 \% \\ \text { Proper supervision } & 24 \% \\ \text { Proper procurement procedures } & 11 \% \\ \text { Good quality purchases } & 15 \% \\ \text { Proper storage and store keeping practices } & 12 \% \\ \text { Utilize skilled and experienced workers } & 12 \% \\ \text { Proper control by management } & 12 \% \\ \text { Improved security } & 8 \% \\ \text { Use of modular designs } & 7 \%\end{array}$

Good quality purchases and proper procurement procedures rates at $15 \%$ and $11 \%$ respectively. Construction materials in the market differ considerably in terms of quality. Poor quality materials are likely to cost less and are found to result in high wastage when used during construction. When there is proper control in a project implementation, scheduled purchases ensures that materials are only brought on site when required so as to avoid long storage duration on site leading to breakages, contamination, misuse and theft. WRAP (2007) suggests the adoption of a robust system that enables the production of accurate estimates of material and action taken to reduce them.
Proper storage practices, which rates at $12 \%$, ensures avoidance of double handling, breakages, contamination, deformation and theft. Vulnerable materials can be kept in lockable stores, in dustbins, in racks and also proper records kept to reduce pilferage. Trained and experienced craftsmen have also been rated as a significant factor which can help to curb material wastage in construction of residential building frames. Proper workmanship ensures that there is minimal materials wastage due to unnecessary cuttings, rework and mishandling. Figure 2 represents suggested measurable stages in material waste management in building residential frame. 


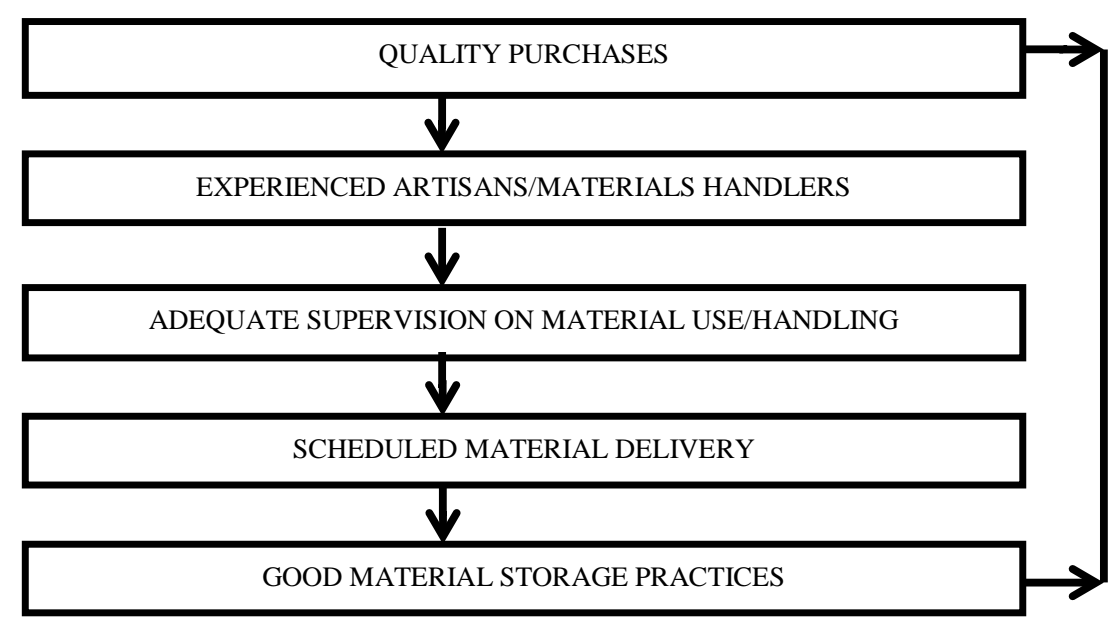

Figure 2. Material waste minimization procedures. Measurable stages (weighted index) in material waste management in building residential frame.

Construction production incorporates, among others, materials flow, order sequence, quality purchases, good storage practices, strict supervision of materials use, and the product development process. The flow of materials from the suppliers through delivery must be integrated by means of just-in-time logistics and employees need to understand their roles. Each particular project management should understand their employees and participate in material waste reduction. This involves engagement, motivation, skill improvement and involvement in daily processes of material usage.

\subsection{DISCUSSION}

The study identifies main causes of material waste in construction of residential building frames in Northern Nairobi. This region predominantly uses conventional methods of construction which generate excessive material waste. The main materials associated with this form of frame construction are concrete, mortar, reinforcement bars, timber, stones, blocks or bricks and roof coverings.

In design and site instruction factors, studies by Adewuyi and Otali (2013), Olusanjo, Panos, and Ezekiel (2014) categorize project designs which do not conform to standards or modular sizes as a major contributor of construction waste. Other studies on "site production and management factors” by Adewuyi and Odesola (2015), Muhwezi, et al (2012) and Al-Hajj \& Karima (2011) concur with the findings of this study where, inexperience among the workers is highly rated as a cause of material waste during construction. In material resource factors, Adewuyi and Odesola (2015)also rate poor schedule of materials procurement, incorrect estimated quantity, over ordering or under ordering, theft / vandalism, wrong handling and poor storage among the highest causes of material waste in their category. Most of the materials for a structural frame construction do not undergo delicate factory manufacturing processes and therefore this attribute does not impact highly on material waste in residential building frame construction. However, studies by Muhwezi, et al (2012), oladirani and olatunji (2013) concur with the findings of this study where manufacturing deficiencies, substandard materials, improper transportation are categorized among the main causes of material waste in construction of buildings. The main cause of material waste in environmental factors in the study is attributed to material deterioration on site, topography and damage by insects. The findings concur with Muhwezi, et al(2012), Adewuyi andOdesola (2015) that severe weather and effects of site conditions closely associated with topography of the site are the highest causes of material waste in their category.

\subsection{CONLUSION}

The study has established that residential building construction projects in Northern Nairobi predominantly use conventional practices. As Angaya (2012) points out, this approach to construction focuses on the uniqueness and the singularity of projects characterized by unique choices of technical solutions, a limited use of platforms, uniquely combined teams and scarcely developed logistics and procurement strategies. In this construction method, concrete, natural walling stones, timber and roof coverings forms the bulk of the materials used in the structural component. Conventional construction methods generate a lot of material waste due to various factors. These factors in effect cause low contractor's profitability, increases cost of production, increases cost of waste management, cause 
environmental degradation and need for high material waste allowance while preparing the bills of quantities.

The study also noted that this region predominantly uses labour contracting. This contracting option has high contribution to material wastage (Ameh and Itodo, 2013).There is usually the tendency for the labour contractor to give less attention to material waste and by extension the craftsmen will have the same attitude.

In order to realize improved low wastage of materials during construction of elemental residential building in Northern Nairobi, this study roots for three areas of activity. One, there should be effective supervision, control of construction activities and materials. This has been found to be the overriding aspect in material waste control in this form of construction. This can be effected if properly trained site supervisors are engaged by the clients. Two, Lean Construction, the new technological approach to construction of residential buildings, should be used. Lean construction has the effect of material waste reduction. It is a rationalized building technique where production management-based approaches to project delivery, organizational techniques used in process of manufacture are applied to erection process. Three, there should be sensitization of the effects of material waste to the main players in the process of construction. These includes site supervisors and workers with possible periodical briefs on waste minimization measures. Project consultants would also be expected to update themselves with the current technological trends so as to recommend different approach to construction of residential buildings within this region.

\section{REFERENCES}

[1] Al-Hajj, A.\& Karima, H. (2011).Material Waste in the UAE Construction Industry: Main Causes and Minimization Practices .Architectural Engineering and Design Management 7:4,221-235.

[2] Ameh, J. \& Itodo, D. (2013). Professionals' views of material wastage on construction sites and cost overruns.Journal of techn.and management in construction5.1,747-757.

[3] Angaya, A. (2012). Influence of lean construction on the performance of housing scheme building projects in Nairobi County. Master's Thesis, University of Nairobi. Nairobi.

[4] Azizi R. \& Hafez, F. (2013). Applying lean thinking in construction and performance improvement in Alexandria. Engineering Journal 52,679-695.

[5] Bossink, B \& Brouwer, J. (1996). Construction waste: quantification and source evaluation Journal of construction engineering \&management March 1996, 55-60.

[6] Branco, C. ( 2007). An effective way to reduce residential construction waste: a case study in Texas. Master's Thesis, A\&M University Texas.Texas
[7] Dainty, A. \& Brooke, R. (2004).Towards improved construction waste minimization: a need for improved supply chain integration? Structural Survey22,1,20-29.

[8] Department of environ.quality, (2013) Integrated Waste Manag. Plan.MontanaGov.USA.

[9] Foster, J. \& Greeno, R. (2006) $7^{\text {th }}$ ed. Struct.and fabric pt 1.Routledge T\&F group. New York

[10] Heilighen, F. \& Joslyn, C. (1992).What is Systems Theory? Cambridge University press. Cambridge.

11] Josephson, P. \& Saukkoriipi, L. (2007).-waste in construction projects: call for new approach.Chalmers University of Technology. Sweden.

[12] Kadir, R. (2006).Construction performance comparison between conventional and industrialized building systems in Malaysia.Structural survey2,5,412-424.

[13] Kamar, K., Hamid, Z., Azman, M. \& Ahamad, M. (2011). Industrialized Building System (IBS): Revisiting Issues of Definition and Classif. International Journal Emerging. Science.,1(2),120-132.

[14] Kioko, C. (2007). Identification of waste determining factors in the Kenyan construction industry Master’s Thesis, University of Nairobi.Nairobi.

[15] Lau, H., Whyte, A. \& Law, P. (2008). Composition and Characteristics of Construction Waste Generated by Residential Housing Project.International.Journal of Environ. Research.2(3),261-268.

[16] Manea, D. (2013).lean production and benefits Review of General Management.Spiru Haret University.17, 1,164-171. Romania

17] Masudi, A., Hassan, C., Mahmood, N., Mokhtar, S. \& Sulaiman, N. (2012). Waste quantification models for estimation of construction and demolition waste generation:

18] International Journal of Global Environmental12. 2/3/4

[19] Mele, C., Pels, J. \& Polese, F. (2009). A brief review of systems theories and their managerial applications.

[20] Service Science2(1/2), 126 - 135,INFORMS Maryland. USA.

[21] Muhwezi, L., Chamuriho, L. \& Lema N. (2012). An investigation into Materials Wastes on Building Construction Projects in Kampala-Uganda- Scholarly Journal of Engineering Research 1(1), 11-18.

[22] Nugroho, A., Tongthong, T. \& Shin, T. (2013). Measurement of the Construction Waste Volume Based on Digital Images. Journal of Civil \& Environmental Engineering13 No: 02.

[23] Pongrácz, E., Phillips, P \& Keiski, R (2004). Evolving the Theory of Waste Management- defining key concepts. Waste Management and the Environment II.78.pp 10.WIT Press. Popov.Greece

[24] Resource venture, ed (2005).Construction Waste Management Guide.Seattle.USA.

[25] The Government of the Republic of Kenya (2007) Kenya vision 2030.Aglobally competitive and prosperous Kenya.Govt press.Nairobi. Kenya.

[26] United nations Environmental Program (n.d).integrated solid waste management.

[27] International Environmental Technology Centre.Nairobi .kenya.

[28] Wahab, A. \& Lawal, A. (2011). -An evaluation of waste control measures in construction industry in Nigeria - African Journal of Environmental Science and Tech.5(3),246-254

[29] Wang, J., Kang, X. \& Tam, V. (2008). An investigation of construction wastes: an empirical study in Shenzhen.Journal of Material Cycles and Waste Management.17. 4, 637-645.

[30] Waste and Resource Action Programme (2007).Waste minimization in construction.Wrap publications.U.K. 